\title{
Authentic Leadership and Altruism: The Mediating Role of Meaningfulness
}

\author{
Mesut Sağnak ${ }^{1}$, Mehmet Kuruöz ${ }^{2, *}$ \\ ${ }^{1}$ Faculty of Education, Ömer Halisdemir University, Turkey \\ ${ }^{2}$ Faculty of Education, Anadolu University, Turkey
}

Copyright $\mathrm{O} 2017$ by authors, all rights reserved. Authors agree that this article remains permanently open access under the terms of the Creative Commons Attribution License 4.0 International License

\begin{abstract}
The purpose of this study was to investigate the mediating effects of meaningfulness on the relationship between authentic leadership and altruistic behavior. The participants consisted of 356 teachers randomly selected from 14 primary and secondary schools in Nigde. Three different instruments were used in this study. The scales were translated using the translation and back translation method. All scales were adapted to the educational context. The validity and reliability of the scales were examined. Pearson correlation coefficient and the structural equation modeling were used for the data analysis. It was found that authentic leadership was positively related to teachers' altruistic behavior and meaningfulness in work. A significant positive relationship was found between altruistic behavior and meaningfulness. It has been determined that meaningfulness fully mediated the relationship between authentic leadership and altruistic behavior.
\end{abstract}

Keywords Authentic, Meaning, Authentic Leadership, Altruism

\section{Introduction}

There is a consensus in all social science literature that the search for meaning is a universal human motive and that loss of meaning leads to psychological deprivation or even disorder [1]. According to Frankly [2], the search for meaning is a basic motive in life. He has said that the meaning can only be made by man himself, therefore the meaning is subjective, and that frustration of man's will to meaning will lead to existential frustration. Philosophically, the meaning of life is the answer to how we live. This question confronts both the ultimate purpose of life and the ethical issue in everyday life. Meaningfulness is experienced in everyday life when virtues such as compassion, honesty, caring, and commitment are transformed into actions [1].

In the meaning literature, it is stated that one of the basic mechanisms that make work meaningful is authenticity.
Authenticity is seen as maintaining the intrinsic value and beliefs that one has [3]. It is asserted that when work is congruent with values, beliefs, attitudes and identity the authentic self develops while will also shape the meaning in work [4]. Individuals who understand the existential structure of life and assume responsibility for their identity and life are considered authentic [1]. Sometimes authentic life and meaningful life are seen equal [5].

The meaning of work in the domain of organizational behavior is based on a psychological perspective based on subjective interpretations of the work experience and interactions of individuals [4]. Meaning in work is defined as the subjective experience of meaning in a particular context [6]. It has been determined that the meaning of work in an organizational environment influences many organizational results [4]. Experienced meaningfulness is considered by researchers as an important psychological state. Less of meaningfulness can lead to work alienation or disengagement [7]. According to organizational theoreticians, through leadership and organizational culture practices, it is possible to make occupationally meaningful work for employees in organizations [1]. Leaders play an important role in influencing or shaping the meaning of work [4].

In the following, theoretical explanations of authentic leadership, altruism and meaningfulness were presented first. Then the research purpose and method are explained. Finally, the results of the research are specified and discussions and suggestions based on them are made.

\section{Theoretical Background}

\subsection{Authentic Leadership}

As a structure the concept of authenticity is defined as being true to oneself [8]. The concept of authenticity has attracted attention with the interest of humanistic psychology [9]. Positive psychology aims to understand organizational dynamics and positive human processes that make positive 
organizational life meaningful [10]. Positive psychology sees the concept of authenticity as the personal experience of a person with his thoughts, feelings, needs, desires or beliefs. Thus, it means a person to be aware of and take appropriate actions expressing the true self in the way s/he actually thinks and believes in. Therefore, authenticity concerns both having a personal experience and acting coherently in true self. In other words it is for a person to tell what he believes or thinks and act accordingly $[10,11,12]$.

Walumbwa [8] defined authentic leadership as a pattern of leader behavior that draws upon and promotes both positive psychological capacities and a positive ethical climate, to foster greater self-awareness, an internalized moral perspective, balanced processing of information, and relational transparency on the part of leaders working with followers, fostering positive self-development (p.94). Authentic leaders behave according to their personal values and beliefs, build credibility and thus gain the trust and respect of followers and encourage different views. Authentic leaders inspire viewers to be authentic in the workplace and thus cause them to experience meaning at work at a higher level [13]. Authentic leaders establish more transparent, open and close relationships with others far from prejudices. Moreover, they exhibit consistent behavior between their beliefs and actions and desire to truly understand their leadership [8].

Authentic leadership has been examined in five dimensions: Self-awareness: It is about someone having self-knowledge. It emphasizes how a person derives and makes meaning of the world. S/he knows how others see him and how $\mathrm{s} /$ he influences others. It shows strengths and weaknesses, as well as values, beliefs, ideals and self-understandings of the person. Relational transparency: The person presents the authentic self to others as the opposite of a fake self. S/he clearly shares the knowledge, expresses his/her feelings and thoughts sincerely. S/he encourages a high level of openness that will provide opportunities for others to express their feelings, thoughts and ideas and thus develops a trust climate. Balanced Processing: Before deciding, leader objectively examines the relevant data, analyzes it, and encourages views that challenge the positions. Internalized moral perspective: This is the internalized and integrated form of self-regulation. $\mathrm{S} / \mathrm{he}$ guides actions based on moral and values standards, contrary to organizational and social pressures. S/he conducts ethical and moral behavior at a high level. Decisions and behaviors are consistent with these internalized values. Authentic leaders are expected to behave in a more ethical manner, and tend to behave in accordance with their value structures $[8,14,15]$.

Authentic leaders are those who are aware of their and others values and moral perspectives, and exhibit confident, hopeful, optimistic, resilient and high moral character. Authentic leadership has a moral component inherently [16]. The authentic leader determines a climate and business process that will improve ethical behavior. They develop a role that can demonstrate high moral responsibility. They send strong messages about ethical behavior to the followers [17].

Avolio et al. [13] argue that authentic leadership affects employee attitudes, behaviors and performance. Ilies et al. [10] discuss influence of authentic leadership on eudaemonic well-being. Positive relationship were found between authentic leadership and ethical leadership, organizational behavior, commitment, satisfaction, trust in leader, positive emotions, internal whistleblowing, innovation, creativity, moral courage, structural empowerment, self-related performance $[3,8,9,14,18,19,20,21]$.

\subsection{Authentic Leadership and Altruism}

Smith, Organ and Near [22] have divided Organization Citizenship Behavior (OCB) into two groups: altruism or helping specific persons and generalized compliance. Later, organizational behavior dimensions were developed as 7 themes or dimensions and helping behavior became an important dimension of OCB [23]. According to Smith et al. [22] altruism emerges as "a class of helping behaviors aimed directly at specific persons. The eliciting stimuli appear to be situational, that is, someone has a problem, needs assistance, or requests a service (p.661). Podsakoff et al. [23] described helping behavior conceptually as "involves voluntarily helping others with, or preventing the occurrence of, work related problems (p.516).

Social psychologists describe altruism in two ways: Firstly, as an ascribed dispositional purpose to help others. Secondly, in terms of manifest behavior and its' congruence without reference to a person's dispositional purpose. The first is the internal state and the second is the behavior with consequences [24]. Altruism is described as an ethical doctrine. The moral value of an individual's action depends on the effect of the consequences only on other people, regardless of the individual's self. Ethically, altruism is seen as a form of consequentialism. Because, altruism depends on the ethical correctness of an action to provide ethically good consequences to others [25]. Altruistic actions are performed for the benefit of others and result from inner need [24].

Leaders influence followers' altruistic behavior. Transformational leaders have altruism based on deontological reasoning. The transactional leaders have utilitarianism / mutual altruism while the transformational leaders have moral altruism. The strategies of a leader's transformational influence stem from moral altruistic motivation. It is mutual altruism if the leader's altruistic concern is combined to self-interest. On the other hand, it is the genuine or moral altruism if the leader's desire to help others bases on a sense of duty apart from self-interest [26].

Research on OCB has shown that altruism is related to morale factors including organizational commitment and job satisfaction [27]. Podsakoff MacKenzie, Moorman and Fetter [28] established that transformational leadership indirect effected on OCB through trust. Du, Q1an and Feng [29] found that shared vision moderated the relationship between altruistic motivation and charitable behavior. Smith 
et al. [22] found that leader support had an indirect effect on altruism via satisfaction. Kidwell and Page [30] determined that individual career satisfaction fully mediated the positive relationship between perceptions of corporate ethical values and self-reported altruism.

\subsection{The Mediating Role of Meaningfulness}

Since the meaning of life is a complex and multidimensional concept, it is difficult to define meaning [4, $5,6]$. The true nature of the meaning of life is as old as the history of mankind [31]. When someone lives meaningfully, it is a subjective experience of the purpose or significance of this life [1]. Frankly [2] argues that people have an intrinsic drive to find the meaning and significance of life. The frustration of this drive leads to distress. Less of meaning causes anxiety and depression together with a negative effect $[5,31]$. Meaningful life requires the importance of being. The feelings, experiences, or perceptions related to the importance of one's being are about to higher aims in life and their realization in relation to existence [7].

Meaningfulness is defined as the assessment of the purpose or goal of a work according to one's own ideals or standards [7]. The literature on the meaning of work in the field of organizational behavior is based on a psychological perspective that implies rooted perceptions of meaning in the subjective interpretations of individual work experiences and interactions. In other words, contrary to social and cultural forces, it has been stated that it includes individual experiences, cognition and feelings $[4,6]$. Every person has to reveal meaning in his own self. Meaning is not significant in existential sense when determined by others. Simply put, the meaning means things that are good for the individual or perceived as true or real, including the experience of all people [1].

Meaning in work is an important part of positive psychology that emphasizes the active development of positive aspects rather than the negative aspects of life. The meaning indicates the relationship between the inner world of the individual and the external context of the workplace [32]. Research on meaningfulness draws a wide range of sketches among many disciplines. It has been pointed out that the meaning of work affects many important organizational outcomes $[4,6,33]$.

Leaders play an important role in influencing or shaping the meaning of work. Primarily, leaders shape the organization's identity, goals, objectives and mission for employees, and it affects the perceptions on the meaning of this work. The reactions of the leaders to various events and situations, and the communication and interpretation symbols about them, have an important effect on the people to form work meaning [4]. The absence of meaning can lead to the alienation or disengagement of one from work. Meaningfulness experiences of workers facilitate both personal growth and job motivation [7].

One of the mechanisms that make work meaningful is authenticity. Authenticity is defined as the sense of harmony or coherence between true self behaviors and perceptions. A sign of authenticity is the degree of belief that people behave in accordance with their values and interests. Authentic mechanisms are concerned with the concept of self as a source of meaning. Activities that develop, explain and apply the concept of authentic self are experienced as meaningfulness, and work meaning is shaped by the consistency between the behavior of one person and the concept of self [4]. A self-alienated person is considered non-authentic by existentialists. On the other side, it is thought that individuals who understand the existential structure of life and assume responsibility for their identity and life are authentic. In the center of the authentic work there is the thought of informed will [1].

The purpose of this study is to investigate the mediating effect of meaningfulness on the relationship between authentic leadership and altruism. In accordance with this goal, the study answers the following questions:

1. Are there any relationship between authentic leadership and altruistic behavior and meaningfulness?

2. Are there any relationship between altruistic behavior and meaningfulness?

3. Does meaningfulness mediate to the relationship between authentic leadership and altruistic behavior?

\section{Method}

\subsection{Participants}

The participants consisted of 356 teachers randomly selected from 7 primary and 7 secondary schools in the center of Nigde, Turkey. $57.7 \%$ of the teachers were female, and $42.3 \%$ were male. The majority of teachers $(41.7 \%)$ were 11 to 20 years of professional experience. The vast majority of the teachers $(86.5 \%)$ were undergraduate degree. Most of teachers (45.9\%) were 31 to 40 years old.

\subsection{Instruments}

Three different instruments were used in this study. The scales were translated using the translation and back translation method. A confirmatory factor analysis was conducted with LISREL 8.7 to test the fit of the model. The fit statistics demonstrated a good or acceptable fit for the model $\left(\mathrm{x}^{2}=592, \mathrm{sd}=307, \mathrm{p}<.01, \mathrm{CFI}=.99\right.$, IFI $=.99, \mathrm{NFI}=.97$, $\mathrm{NNFI}=.98, \mathrm{RMSEA}=.05, \mathrm{AGFI}=.86[34,35,36,37]$. The participants used a 5-point Likert type scale ranging from 1 (strongly disagree) to 5 (strongly agree).

\section{The Authentic Leadership Inventory (ALI)}

The Authentic Leadership Inventory developed by Neider and Schriesheim [38] was used with the aim of determining authentic leadership behaviors of school principals. The scale contains 16 items and four sub-dimensions as self-awareness, relational transparency, balanced processing, internalized moral perspective. Each of these dimensions has four items. Examples items are: "My leader clearly states 
what he/she means (R)" and "My leader carefully listens to alternative perspectives before reaching a conclusion (B)". The reliability of the scale was .93 .

\section{Altruism Scale}

Altruism scale, as a dimension of Organizational Citizenship Behavior Scale, developed by Podsakoff et al. [28] was used for teachers' altruistic behavior in schools. The scale consists of five items. Examples of items are: "Helps others who have been absent", "Helps others who have been heavy workloads". The reliability level of the scale was .87 .

\section{Meaningfulness Scale}

Meaningfulness was measured using Psychological Meaningfulness Scale developed by May et al [7]. The scale consists of six items. Examples of items are: "The work I do on this job is very important to me" and "My job activities are personally meaningful to me". The reliability of the scale was .90 .

The structural equation modeling was conducted using the LISREL 8.7 computer program. Baron and Kenny's [39] traditional approach was used for testing mediating model. Mean, standard deviation and Pearson product correlation coefficient were used for data analysis.

\section{Results}

Table 1 presents the means, standard deviations and correlations for the authentic leadership, altruism, meaningfulness.

Table 1. Mean, Standard Deviation and Correlation

\begin{tabular}{|l|c|c|c|c|c|}
\hline Valuables & $\overline{\mathrm{X}}$ & Ss & 1 & 2 & 3 \\
\hline 1. Authentic leadership & 4.11 & 0.63 & 1 & $0.58^{*}$ & $0.45^{*}$ \\
\hline 2. Altruism & 4.41 & 0.57 & & 1 & $0.75^{*}$ \\
\hline 3. Meaningfulness & 4.61 & 0.51 & & & 1 \\
\hline
\end{tabular}

$* \mathrm{p}<0.01$

As it has seen in Table 1, for authentic leadership the mean found as $\bar{X}=4.11$, for altruism as $\bar{X}=4.41$ and for meaningfulness as $\bar{X}=4.61$. It was found that that authentic leadership was significantly related to altruism $(\mathrm{r}=0.58$, $\mathrm{p}<.01)$ and meaningfulness $(\mathrm{r}=0.45, \mathrm{p}<.01)$. Results showed that there was a significant relationship between altruism and meaningfulness $(\mathrm{r}=0.75, \mathrm{p}<.01)$. The structural equation modeling was administrated using LISREL 8.7 computer program and results are presented in figure 1.

Figure 1 shows that authentic leadership was a significant predictor of altruism $(\beta=0.57, \mathrm{p}<.01)$ and meaningfulness $(\beta=0.45, p<.01)$. There was a significant relationship between altruism and meaningfulness $(\beta=0.70, \mathrm{p}<.01)$. Meaningfulness fully mediated the relationship between authentic leadership and altruism $(\beta=0.07, \mathrm{p}<0.01, \mathrm{t}=1.33)$. According to statistical considerations proposed by Baron and Kenny [39], it can be said that meaningfulness fully mediated the relationship between authentic leadership and altruistic behavior.

\section{Discussion}

This study purposed to investigate the relationship among authentic leadership, altruism and meaningfulness. Results indicated that authentic leadership was positively related to altruism and meaningfulness. A significant relationship was found between altruism and meaningfulness. It was determined that meaningfulness fully mediated the relationship between authentic leadership and altruism. These findings coincide with the results of previous empirical researches.

Authenticity means a person to take appropriate actions expressing the true self in what $\mathrm{s} / \mathrm{he}$ actually thinks and believes in. Authenticity is seen as sustaining the internal values and beliefs that a person has. Thus, authenticity involves the action of persons according to their values. In other words it is for a person to tell what he believes or thinks and act accordingly $[3,10,11,12]$.

Altruism is seen as a moral constituent and is defined the act of helping the others without expecting a benefit. Leaders influence followers' altruistic behavior. It is asserted that the transactional leaders have utilitarianism altruism while the transformational leaders have moral altruism. The strategies of a leader's transformational influence stem from moral altruistic motivation $[22,23,24,25,26]$. According to researches, positive relationship was found between altruism and commitment, job satisfaction, trust, charitable behavior, ethical values $[27,28,29,30]$.

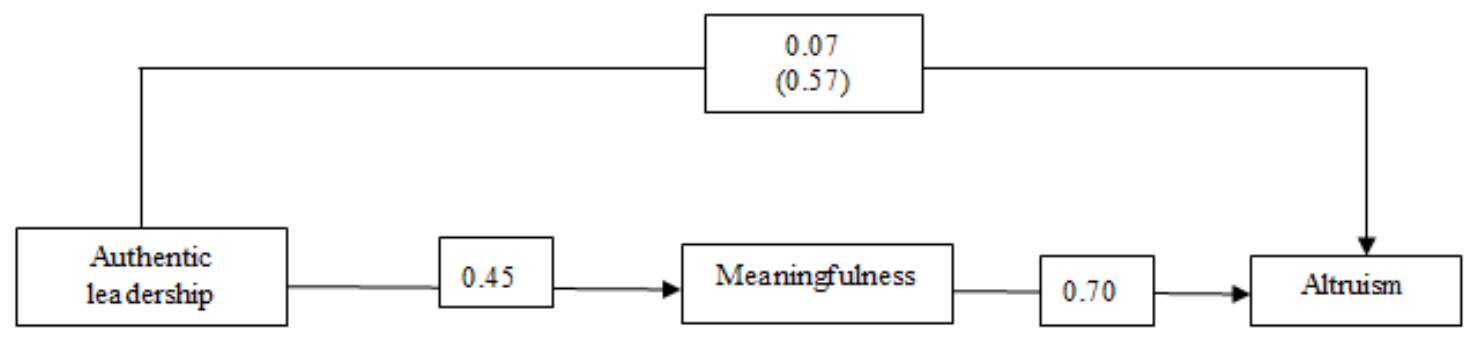

Figure 1. The Mediating Effect of Meaningfulness 
Authentic leaders make work meaningful. Meaningfulness is defined as the assessment of the purpose or goal of a work according to one's own ideals or standards [7]. It was asserted that the meaningfulness is related to many organizational variables $[4,6,33]$. For example May et al. [7] found that meaningfulness was positively related to commitment.

Leaders play an important role in influencing or shaping the meaning of work. First of all, leaders shape the vision for employees, which affect perceptions on meaning of the work. The reactions of the leaders to various events and situations, and the communication and interpretation symbols about them, have an important effect on the people to form work meaning [4]. Authentic leaders build credibility and thus gain the trust and respect of followers. They inspire viewers to be authentic in the workplace and thus cause them to experience meaning at work at a higher level $[8,13]$. Ghadi and Fernendo [40] found a relationship between transformational leadership and followers' attributes of work engagement. Employees' perceptions of meaning in work partially mediate this relationship.

This study found that authentic leaders lead to altruistic behavior of teachers through meaningfulness. It is indicated that authentic leadership raises altruism, and it causes meaningfulness. It can be said that leaders need to show altruistic behavior in order to make work meaningful in schools. It has been found that altruistic behavior in school leads to meaningfulness. This research is designed quantitatively, and this thesis or model can be confirmed by qualitative or mixed research methods.

\section{REFERENCES}

[1] Lips-Wiersma, M., \& Morris, L. (2009). Discriminating between meaningful work and the management meaning. Journal of Business Ethics, 88, 491-511.

[2] Frankly, V. E. (1992). Mans' search for meaning: An introduction to logotherapy. Fourth edition. Boston: Beacon press.

[3] Zhou, J. (2014). Mediating role of employee emotions in the relationship between authentic leadership and employee innovation. Social Behavior and Personality, 42 (8), $1267-1278$

[4] Rosso, B. D., Dekas, K. H., \& Wrzesniewski, A. (2010). On the meaning of work: A theoretical integration and review. Research in Organizational Behavior, 30, 91-127.

[5] Steger, M. F. (2005). Development and validation of the meaning in life questionnaire: A measure of eudaimonic wellbeing. (Unpublished doctoral dissertation). The University of Minnesota.

[6] Schnell, T., \& Höge, T., \& Pollet, E. (2013). Predicting meaning in work: Theory, data, implications. The Journal of Positive Psychology, 8 (6), 543-554.

[7] May, D. R., Gilson, R. L., \& Harter, L. M. (2004). The psychological conditions of meaningfulness, safety and availability and the engagement of the human spirit at work. Journal of Occupational and Organizational Psychology, 77, 11-37.

[8] Walumbwa, F. O., Avolio, B. J., Gardner, W. L., Wernsing, T.S., \& Peterson, S. J. (2008). Authentic leadership: Development and validation of a theory-based measure. Journal of Management, 34 (1), 89-126.

[9] Rahimnia, F., \& Sharifirad, M. S. (2015). Authentic leadership and employee well-being: The mediating role of attachment insecurity. Journal of Business Ethics, 132, 363-377.

[10] Ilies, R., Morgeson, F. P., \& Nahrgang, J. D. (2005). Authentic leadership and eudaemonie well-being: Understanding leader-follower outcomes. The Leadership Quarterly, 16, 373-394.

[11] Gardner, W.L., Avolio, B. J., Luthans, F., May, D. R., \& Walumbwa, F. (2005). Can you see the real me? A self-based model of authentic leader and follower development. The Leadership Quarterly, 16, 343-372.

[12] Gardner, W. L., Cogliser, C. C., Davis, K. M., \& Dickens, M. P. (2011). Authentic leadership: A review of the literature and research agenda. The Leadership Quarterly, 22, 1120-1145.

[13] Avolio, B. J., Gardner, W.L., Walumbwa, F. O., Luthans, F., \& May, D. R. (2004). Unlocking the mask: A look at the process by which authentic leaders impact follower attitudes and behaviors. The Leadership Quarterly, 15, 801-823.

[14] Hannah, S. T., Avolio, B. J., \& Walumbwa, F. O. (2011). Relationship between authentic leadership, moral courage, and ethical and pro-social behaviors. Business Ethics Quarterly, 21 (4), 555-578.

[15] Rego, A., Sousa, F., Marques, C., \& Cunha, M. P. (2014). Hope and positive affect mediating the authentic leadership and creativity relationship. Journal of Business Research, 67, 200-210.

[16] Avolio, B. J., \& Gardner, W. L. (2005). Authentic leadership development: Getting to the root of positive forms of leadership. The Leadership Quarterly, 16, 315-338.

[17] May, D. R., Chan, A. Y. L., Hodges, T. D., \& Avolio, B. J. (2003). Developing the moral component of authentic leadership. Organizational Dynamics, 32, 247-260.

[18] Agote, L., Aramburu, N., \& Lines, R. (2016). Authentic leadership perception, trust in the leader, and followers' emotions in organizational change processes. The Journal of Applied Behavioral Science, 52 (1), 35-63.

[19] Liu, S-m., Liao, J-q., \& Wei, H. (2015). Authentic leadership and whistleblowing: Mediating roles of psychological safety and personal identification. Journal of Business Ethics, 131, 107-119.

[20] Rego, A., Sousa, F., Marques, C., \& Cunha, M. P. (2012). Authentic leadership promoting employees' psychological capital and creativity. Journal of Business Research, 65, 429-437.

[21] Wong, C. A., \& Laschinger, H. K. S. (2012). Authentic leadership, performance, and job satisfaction: The mediating role of empowerment. Journal of Advanced Nursing, 69, 947-959. 
[22] Smith, C. A., Organ, D. W., \& Near, J. P. (1983). Organizational citizenship behavior: Its nature and antecedents. Journal of Applied Psychology, 68 (4), 653-663.

[23] Podsakoff, P. M., MacKenzie, S. B., Paine, J. B., \& Bachrach, D. G. (2000). Organizational citizenship behaviors: A critical review of the theoretical and empirical literature and suggestions for future research. Journal of Management, 26 (3), 513-563.

[24] Mendonca, M., \& Kanungo, R. N. (2007). Ethical leadership. New York: Open University Press.

[25] Furnham, A., Treglown, L., Hyde, G., \& Trickey, G. (2016). The bright and dark side of altruism: Demographic, personality traits, and disorders associates with altruism. Journal of Business Ethics, 134, 359-368.

[26] Kanungo, R. N. (2001). Ethical values of transactional and transformational leaders. Canadian Journal of Administrative Sciences, 18 (4), 257-265.

[27] Koster, F. (2014). "When two worlds collide": Career satisfaction and altruistic organizational citizenship behavior. International Journal of Business Science and Applied Management, 9 (1), 1-12.

[28] Podsakoff, P. M., MacKenzie, S. B., Moorman, R. H., \& Fetter, R. (1990). Transformational leader behaviors and their effects on followers' trust in leader, satisfaction, organizational citizenship behaviors. Leadership Quarterly, 1 (2), 107-142.

[29] Du, L., Qian, L., \& Feng, Y. (2014). Influences of altruistic motivation, shared vision, and perceived accessibility on microcharity behavior. Social Behavior and Personality, 42 (10), 1639-1650.

[30] Kidwell, R. E., \& Godkin, L., \& Fleischman, G. M. (2011). Corporate ethical values and altruism: The mediating role of career satisfaction. Journal of Business Ethics, 101, 509-523.

[31] Morgan, J., \& Farsides, T. (2009). Measuring meaning in life. Journal of Happiness Studies, 10, 197-214.
[32] Cartwright, S., \& Hames, N. (2006). The meaning of work: The challenge of regaining employee engagement and reducing cynicism. Human Resource Management Review, 16, 199-208.

[33] Chalofsky, N. (2003). An emerging construct for meaningful work. Human Resource Development International, 6 (1), 69-83.

[34] Hu, L., \& Bentler, P. M. (1999). Cutoff criteria for fit indexes in covariance structure analysis: Conventional criteria versus new alternatives. Structural Equation Modeling: A Multidisciplinary Journal, 6 (1), 1-55.

[35] Schermelleh-Engel, K., Moosbrugger, H., \& Müller, H. (2003). Evaluating the fit of structural equation models: Tests of significance and descriptive goodness-of-fit measures. Methods of Psychological Research Online, 8 (2), 23-74.

[36] Schumacker, R. E., \& Lomax, R. G. (2004). A beginner's guide to structural equation modeling. New Jersey: Lawrence Erlbaum Associates, Inc.

[37] Yılmaz, V., \& Çelik, H. E. (2009). Lisrel ile yapısal eşitlik modellemesi. Ankara: Pegem A Yayınları.

[38] Neider, L. L., \& Schriesheim, C. A. (2011). The Authentic Leadership Inventory (ALI): Development and empirical tests. The Leadership Quarterly, 22, 1146-1164.

[39] Baron, R. M., \& Kenny, D. A. (1986). The moderator-mediator variable distinction in social psychological research: Conceptual, strategic, and statistical considerations. Journal of Personality and Social Psychology, 51 (6), 1173-1182.

[40] Ghadi, M. Y., \& Fernado, M. (2013). Transformational leadership and work engagement: The mediating effect of meaning in work. Leadership \& Organization Development Journal, 34 (6), 532-550. 